\title{
Impacts of Membrane Biophysics in Alzheimer's Disease: From Amyloid Precursor Protein Processing to $\mathrm{A} \beta$ Peptide-Induced Membrane Changes
}

\author{
Sholpan Askarova, Xiaoguang Yang, and James C.-M. Lee \\ Department of Biological Engineering, University of Missouri, Columbia, MO 65211, USA \\ Correspondence should be addressed to James C.-M. Lee, leejam@missouri.edu
}

Received 27 October 2010; Revised 30 December 2010; Accepted 21 January 2011

Academic Editor: Katsuhiko Yanagisawa

Copyright (C) 2011 Sholpan Askarova et al. This is an open access article distributed under the Creative Commons Attribution License, which permits unrestricted use, distribution, and reproduction in any medium, provided the original work is properly cited.

\begin{abstract}
An increasing amount of evidence supports the notion that cytotoxic effects of amyloid- $\beta$ peptide (A $\beta$ ), the main constituent of senile plaques in Alzheimer's disease (AD), are strongly associated with its ability to interact with membranes of neurons and other cerebral cells. $\mathrm{A} \beta$ is derived from amyloidogenic cleavage of amyloid precursor protein (A $\beta \mathrm{PP})$ by $\beta$ - and $\gamma$-secretase. In the nonamyloidogenic pathway, A $\beta \mathrm{PP}$ is cleaved by $\alpha$-secretases. These two pathways compete with each other, and enhancing the non-amyloidogenic pathway has been suggested as a potential pharmacological approach for the treatment of $A D$. Since A $\beta P P$, $\alpha-, \beta$-, and $\gamma$-secretases are membrane-associated proteins, $\mathrm{A} \beta \mathrm{PP}$ processing and $\mathrm{A} \beta$ production can be affected by the membrane composition and properties. There is evidence that membrane composition and properties, in turn, play a critical role in $A \beta$ cytotoxicity associated with its conformational changes and aggregation into oligomers and fibrils. Understanding the mechanisms leading to changes in a membrane's biophysical properties and how they affect A $\beta$ PP processing and $A \beta$ toxicity should prove to provide new therapeutic strategies for prevention and treatment of $\mathrm{AD}$.
\end{abstract}

\section{Introduction}

The senile plaque composed of neurotoxic amyloid- $\beta$ peptide $(\mathrm{A} \beta)$ is a pathologic characteristic of Alzheimer's disease (AD) $[1-6] . A \beta$ is derived from the cleavage of a type I membrane protein, $(\mathrm{A} \beta \mathrm{PP})$, by $\beta$ - and $\gamma$-secretases [7]. Alternatively, A $\beta \mathrm{PP}$ can be cleaved by $\alpha$-secretase to produce a neurotrophic, neuroprotective $\alpha$-secretase-cleaved soluble $\mathrm{A} \beta \mathrm{PP}\left(\mathrm{sA} \beta \mathrm{PP}_{\alpha}\right)$ through a nonamyloidogenic pathway [8]. These two pathways compete with each other, and increasing $\mathrm{sA} \beta \mathrm{PP}_{\alpha}$ has been suggested as a potential therapy for $\mathrm{AD}$ [9]. The cleavage of $\mathrm{A} \beta \mathrm{PP}$ by $\beta$-secretase (BACE), the primary step to produce $A \beta[10,11]$, occurs mainly in lipid rafts, which are highly ordered membrane microdomains enriched in cholesterol, sphingolipids and saturated phospholipids [12-17]. On the other hand, the activity of $\alpha$ secretases is favored in nonraft domains [18]. Therefore, $\mathrm{A} \beta \mathrm{PP}$ processing can be altered by manipulating membrane lipid composition, such as removal of cholesterol and sphingolipids [19-22]. Since A $\beta \mathrm{PP}, \alpha-, \beta$-, and $\gamma$-secretases are membrane proteins, $\mathrm{A} \beta \mathrm{PP}$ processing can be also affected by the biophysical membrane properties such as membrane fluidity and molecular order [19-26].

Amyloidogenic cleavage of the A $\beta$ PP leads to the production of $A \beta$ peptides of different length [27]. An increasing amount of evidence supports the notion that cytotoxic effects of $A \beta$ are strongly associated with its ability to interact with membranes of neurons and other cerebral cells, astrocytes, microglial, and cerebral endothelial cells. $\mathrm{A} \beta$ peptides in different forms can directly bind to membrane molecules and alter biophysical membrane properties [28-33]. A $\beta$ can also indirectly affect membrane properties by binding to membrane receptors and triggering downstream signaling pathways. Moreover, there is evidence that $A \beta_{1-42}$ oligomers can accelerate the amyloidogenic processing of $\mathrm{A} \beta \mathrm{PP}$ by changing membrane physical properties and interacting with lipid raft-related ganglioside GM-1 [25]. Membrane properties and composition, and the presence of metal ions, 
in turn, play critical roles in $\mathrm{A} \beta$ cytotoxicity associated with its conformational changes, aggregation into oligomers and fibrils, and ability to interact with membrane molecules [3440].

In this paper, we summarize the effects of membrane composition and properties on $\mathrm{A} \beta \mathrm{PP}$ processing and interactions of physiologically relevant $\mathrm{A} \beta_{1-40}$ and $\mathrm{A} \beta_{1-42}$ with membranes studied in membrane models, cell cultures, and in vivo. Understanding the mechanisms leading to changes in a membrane's biophysics and how they cause changes in $\mathrm{A} \beta \mathrm{PP}$ processing and $\mathrm{A} \beta$ toxicity should provide insights into new therapeutic strategies for prevention and treatment of $\mathrm{AD}$.

\section{Role of Physical Membrane Properties in A $\beta$ PP Processing}

2.1. Cholesterol on Physical Properties of Membranes and $A \beta P P$ Processing. Cholesterol is an essential component of the cellular membrane and plays a vital role in the regulation of membrane functions. Distribution of cholesterol within the plasma membrane is not even: the highest level of free cholesterol inside the plasma membrane is found in cytofacial bilayer leaflet $[41,42]$. The exofacial leaflet contains substantially less cholesterol, and it is mostly condensed in lipid rafts, which are more tightly packed than nonlipid raft domains due to intermolecular hydrogen bonding involving sphingolipid and cholesterol [43]. This asymmetric distribution of cholesterol is altered by aging: it is significantly increased in exofacial leaflet with increasing age $[42,44]$. Membrane cholesterol levels can also be modulated by specific inhibitors of the cellular biosynthesis such as statins (3-Hydroxy-3-methylglutaryl coenzyme A reductase (HMG-CoA) inhibitors), or it can be selectively extracted from plasma membrane by methyl- $\beta$-cyclodextrin $(\mathrm{M} \beta \mathrm{CD})$ [41]. The percentage of cholesterol in phospholipid bilayers affects many biophysical parameters of lipid bilayers, such as thickness, thermomechanical properties, molecular packing, conformational freedom of phospholipid acyl chains and water, molecular oxygen permeability, membrane hydrophobicity, membrane excitability in neurons, internal dipolar potential, and membrane fluidity [45-51].

It has been shown that intracellular cholesterol homeostasis regulates $\mathrm{A} \beta \mathrm{PP}$ processing [52]. A model of membrane compartmentalization has been suggested for $\mathrm{A} \beta \mathrm{PP}$ present in two cellular pools, one associated with the cholesterol-enriched lipid rafts, where $\mathrm{A} \beta$ is generated, and another outside of rafts (i.e., nonraft domains), where $\alpha$-cleavage occurs [13]. It has been reported that membrane cholesterol depletion decreased the content of $\mathrm{A} \beta \mathrm{PP}$ in cholesterol and sphingolipid-enriched membrane microdomains and subsequently inhibited the amyloidogenic pathway to produce $\mathrm{A} \beta[19,53]$. In contrast, cholesterol accumulation in Niemann Pick type C (NPC) model cells has been shown to shift A $\beta$ PP localization to lipid rafts [54]. Exposure of cholesterol to astrocytes, primary neurons, and glial cultures inhibited the secretion of $\mathrm{SAPP}_{\alpha}$ and reduced cell viability [55-57]. It has been demonstrated that cholesterol decreased the secretion of $\operatorname{sAPP}_{\alpha}$ by interfering with $\mathrm{A} \beta \mathrm{PP}$ maturation and inhibiting glycosylation of the protein [56]. Furthermore, some studies showed that cholesterol levels in the membranes were positively correlated with $\beta$-secretase activity [58], while lovastatin enhanced the $\alpha$ secretase activity [55].

The results of another study showed that the cholesterol transport inhibitor, U18666a, increased $\mathrm{sA} \beta \mathrm{PP}_{\alpha}$ secretion and intracellular $\mathrm{A} \beta \mathrm{PP}_{\alpha}$ levels and reduced secretion of $\mathrm{A} \beta_{1-40}$ in N2aAPP "Swedish" cells [59]. Inhibition of intracellular cholesterol transport also altered presenilin localization and $\mathrm{A} \beta \mathrm{PP}$ processing in neuronal cells [60]. Similarly, inhibition of Acyl-coenzyme A:cholesterol acyltransferase (ACAT) modulated A $\beta$ PP trafficking and reversed diffuse brain amyloid pathology in aged A $\beta$ PP transgenic mice [6163]. Nevertheless, lowering cholesterol by treatment with statins was found to reduce $[13,21,64]$ or enhance $A \beta$ generation, depending on the condition of the study [65]. One possible explanation for the controversial results is that moderate reduction in cholesterol is associated with a disorganization of detergent-resistant membranes (DRMs) or lipid rafts, allowing more $\beta$-site $\mathrm{A} \beta \mathrm{PP}$ cleaving enzyme (BACE) to contact $\mathrm{A} \beta \mathrm{PP}$ and resulting in increased $\mathrm{A} \beta$ generation, whereas a strong reduction of cholesterol inhibits the activities of BACE and $\gamma$-secretase, resulting in a decrease in $\mathrm{A} \beta$ generation [14]. On the other hand, in the low-dose statin treatment conditions [65], enchanted $A \beta$ production could be a result of feedback upregulation of HMG-CoA mPNA and increased cholesterol level.

Consistent with the membrane compartmentalization model, cellular cholesterol depletion results in an increase in membrane fluidity, a parameter which characterizes an average lateral motion of phospholipid molecules within the lipid bilayer [19, 66-69]. On the other hand, an increase in membrane fluidity has been demonstrated to shift A $\beta P P$ processing to nonamyloidogenic cleavage by $\alpha$-secretase [54-56, 65-68]. It has been reported that the removal of cholesterol with methyl- $\beta$-cyclodextrin or treatment with lovastatin increased membrane fluidity, which resulted in higher expression of the $\alpha$-secretase and impaired internalization of $\mathrm{A} \beta \mathrm{PP}[19]$. At the same time, cholesterol enrichment has been shown to reduce membrane fluidity $[70,71]$. Cholesterol enrichment that impeded membrane fluidity may lower $\mathrm{sA} \beta \mathrm{PP}_{\alpha}$ production by hindering the interaction of the substrate with its proteases [72]. Interestingly, substitution of cholesterol by the steroid 4-cholesten-3one induces minor change in membrane fluidity and reduces $\mathrm{sA} \mathrm{PP}_{\alpha}$ secretion, whereas substitution of cholesterol by lanosterol increases membrane fluidity and $\mathrm{sA} \beta \mathrm{PP}_{\alpha}$ secretion [19]. These results suggest reversible effects of cholesterol on the $\alpha$-secretase activity depending on membrane fluidity.

Many studies support the notion that $\mathrm{A} \beta$ production occurs in endosomes $[22,73-77]$. Since A $\beta \mathrm{PP}$ is a transmembrane protein, its internalization from the plasma membrane is regulated by key regulators of endocytosis, such as Rab5, and this process has been found to enhance $\mathrm{A} \beta \mathrm{PP}$ cleavage by $\beta$-secretase leading to increased $A \beta$ levels [78]. In contrast, $\mathrm{A} \beta \mathrm{PP}$, lacking its cytoplasmic internalization motif, can 
accumulate at the plasma membrane and undergo cleavage by $\alpha$-secretase $[10,11]$. Cholesterol has been demonstrated to increase clathrin-dependent $\mathrm{A} \beta \mathrm{PP}$ endocytosis in a dosedependent and linear manner [79]. There were also studies demonstrating that alterations in cholesterol transport from late endocytotic organelles to the endoplasmic reticulum had important consequences for both $\mathrm{A} \beta \mathrm{PP}$ processing and the localization of $\gamma$-secretase-associated presenilins [60]. It has been suggested that cholesterol increase in $\mathrm{AD}$ could be responsible for the enhanced internalization of clathrin-, dynamin2-, Eps15-, and Rab5-dependent endocytosis of $\mathrm{A} \beta \mathrm{PP}$ and the ensuing overproduction of $\mathrm{A} \beta$ [79]. Alternatively, $A \beta P P$ internalization could be reduced by lowering cholesterol, which leads to an increase in membrane fluidity, $\mathrm{A} \beta \mathrm{PP}$ accumulation on the cell surface, and increased $\mathrm{sA} \beta \mathrm{PP}_{\alpha}$ secretion [19].

\subsection{Fatty Acids on Membrane Physical Properties and $A \beta P P$} Processing. Fatty acids are other essential components of the cellular membranes. They are important ingredients in various dietary sources and play a central role in the normal development and function of the brain [80-83]. For example, long-chain polyunsaturated fatty acids (PUFAs) of the $\omega-6$ and $\omega-3$ series, the major polyunsaturated fatty acids in the central nervous system [84], are essential for prenatal brain development and normal brain functions $[83,85,86]$. Animals specifically deficient in dietary $\omega-3$ fatty acids have been demonstrated to have reduced visual acuity and impaired learning ability [86, 87]. Diets enriched in long-chain $\omega$-3 PUFA (DHA) have been shown to modulate gene expression for brain function, improve synaptic and neurotransmitter functions of neurons, enhance learning and memory performances, and display neuroprotective properties [86, 88-90]. Arachidonic acid (AA), another abundant fatty acid in the brain, is a second messenger [91] and a precursor for the synthesis of eicosanoids [92]. The presence of PUFAs in neuronal cells influences cellular function both directly, through effects on membrane properties, and indirectly by acting as precursors for lipidderived messengers $[93,94]$.

In fact, the disturbed metabolism of fatty acids is associated with $\mathrm{AD}$ [95]. For instance, lower levels of DHA have been reported in serum samples taken from $\mathrm{AD}$ patient [96], while greater consumption of DHA has significantly reduced the likelihood of developing AD [97]. Dietary $\omega$ 3 PUFA depletion has been shown to activate caspases and decrease NMDA receptors in the brain of a transgenic mouse model of AD [98]. DHA and curcumin have been shown to suppress $A \beta$-induced phosphorylation of tau tangles and the inactivation of insulin receptors in primary rat neurons [99]. Recently, reduced expression of the neuronal sortilin-related receptor SorLA/LR11 (LR11), a sorting protein that regulates APP trafficking to $\beta$ - and $\gamma$-secretases, was identified as a probable genetic risk factor for late-onset Alzheimer's disease [100]. DHA, in turn, has been found to increase LR11 expression in primary rat neurons, human neuronal line, and aged nontransgenic and DHA-depleted APPsw AD transgenic mice [101]. In 15-month-old $\mathrm{A} \beta \mathrm{PP} /$ presenilin-1 mice, DHA supplementation improved spatial memory, decreased $\mathrm{A} \beta$ deposition, and slightly increased relative cerebral blood volume, indicating that a DHA-enriched diet can diminish AD-like pathology [102].

Dietary fatty acids may integrate into cell membranes to change their physical properties and subsequently alter cell functions. The ability of fatty acids to modulate membrane properties and functions [90, 94, 103-109] depends both on the saturation degree of the fatty acids and the trans/cis ratio of the unsaturated fatty acids [110-113]. For example, diets enriched in unsaturated PUFAs, DHA, and AA have been shown to increase membrane fluidity of neurons and other cells $[71,89,114,115]$. DHA has been also capable of counteracting cholesterol-induced decreases in platelet membrane fluidity and modulating platelet hyperaggregation [71]. Similarly, cis-polyunsaturated linolenic, $\alpha$-linoleic, and eicosatrienoic fatty acids increased membrane fluidity [110]. In contrast, membrane incorporation of saturated acids led to decreased membrane fluidity $[109,112,116]$. PUFAs have also been shown to affect many other membrane properties, such as molecular order, compressibility, permeability, fusion, and protein activity $[117,118]$.

Since $\mathrm{A} \beta \mathrm{PP}, \alpha-, \beta$-, and $\gamma$-secretases are membrane protein molecules, $\mathrm{A} \beta \mathrm{PP}$ processing can be altered by manipulating the membrane lipid composition. It was mentioned before that an increase in membrane fluidity has resulted in an increase in nonamyloidogenic cleavage by $\alpha$-secretase to produce $\mathrm{sA} \beta \mathrm{PP}_{\alpha}[19,25]$. At the same time, enrichment of cell membranes with PUFAs increases membrane fluidity and, consequently, promotes nonamyloidogenic processing of $A \beta P P$ [113]. It has been shown that a typical Western diet (with $40 \%$ saturated fatty acids and $1 \%$ of cholesterol) fed to transgenic $\mathrm{A} \beta \mathrm{PP} / \mathrm{PS} 1$ mice increased $\mathrm{A} \beta$, while diets supplemented with DHA decreased $\mathrm{A} \beta$ levels compared to regular diet [119]. Similarly, DHA has been shown to decrease the amount of vascular $A \beta$ deposition [120] and reduce cortical $\mathrm{A} \beta$ burden [121] in the aged Alzheimer mouse model. In this model, DHA modulated $\mathrm{A} \beta \mathrm{PP}$ processing by decreasing both $\alpha$ - and $\beta$-A $\beta$ PP C-terminal fragment products and full-length $\mathrm{A} \beta \mathrm{PP}[121]$. DHA has also been shown to stimulate nonamyloidogenic $\mathrm{A} \beta \mathrm{PP}$ processing resulting in reduced $A \beta$ levels in cellular models of Alzheimer's disease [122]. At the same time, the study of the effects of fatty acids on cell membrane fluidity and $\mathrm{sA} \beta \mathrm{PP}_{\alpha}$ secretion in relation to degrees of unsaturation has suggested that not all unsaturated fatty acids, but only those with 4 or more double bonds, such as arachidonic acid (20:4), eicosapentaenoic acid (20:5), and DHA (22:6), increased membrane fluidity and led to an increase in $\mathrm{sA} \beta \mathrm{PP}_{\alpha}$ secretion, while oleic acid (18:1), linoleic acid $(18: 2)$, and $\alpha$-linolenic acid $(18: 3)$ did not [113]. Moreover, the results of another experiment have indicated that treatment of PSwt-1 cells with oleic acid and linoleic acid increased $\gamma$-secretase activity and $\mathrm{A} \beta$ production [123].

2.3. Phospholipases $A_{2}$ on Membrane Physical Properties and $A \beta P P$ Processing. Phospholipases $\mathrm{A}_{2}\left(\mathrm{PLA}_{2} \mathrm{~s}\right)$ are ubiquitously distributed in mammalian cell enzymes that catalyze 
the hydrolysis of fatty acids from $s n-2$ position of phospholipids. $\mathrm{PLA}_{2} \mathrm{~S}$ are classified into three major families: calcium-dependent cytosolic PLA $2\left(\mathrm{CPLA}_{2}\right)$, secretory PLA $\left(\mathrm{sPLA}_{2}\right)$, and calcium-independent $\mathrm{PLA}_{2}\left(\mathrm{iPLA}_{2}\right)$. These enzymes are responsible for maintenance of phospholipid homeostasis in the cell membrane. They are also important in production of lipid mediators, such as arachidonic acid. Activation of $\mathrm{PLA}_{2} \mathrm{~S}$ has been implicated in diverse cellular responses such as mitogenesis, differentiation, inflammation, and cytotoxicity, and changes in PLA $2 \mathrm{~s}^{\prime}$ activities occur in many neurodegenerative diseases, including $\mathrm{AD}$ [124-136].

It has been shown that immunoreactivity of $\mathrm{CPLA}_{2}$ (group IIA and IVA) increased in reactive astrocytes in severe AD patient brains [124-126]. Upregulations of sPLA 2 -IIA and $\mathrm{PLA}_{2}$-IVA were reported in the hippocampus of $\mathrm{AD}$ patients $[126,137,138]$. The levels of activated $\mathrm{CPLA}_{2}-$ IVA were also increased in the hippocampus of $h A \beta P P$ mice [138]. Furthermore, $\mathrm{A} \beta$ has been shown to activate $\mathrm{CPLA}_{2}$ in primary rat and mouse brain endothelial cells, astrocytes, cortical neurons, and in PC12 cells [139-143]. Contradictory, both increased and reduced $\mathrm{PLA}_{2}$ activity has been reported in platelets of $\mathrm{AD}$ patients [144, 145]. At the same time, $\mathrm{PLA}_{2}$ activity was significantly decreased in the parietal and, to a lesser degree, in frontal cortex of AD brains. Lower $\mathrm{PLA}_{2}$ activity correlated significantly with an earlier onset of the disease, higher counts of neurofibrillary tangles and senile plaques and an earlier age of death, indicating a relationship between abnormally low $\mathrm{PLA}_{2}$ activity and a more severe form of the illness [146].

$\mathrm{PLA}_{2} \mathrm{~S}$ play key roles in modulation of membrane properties under pathological and physiological conditions. For instance, in immortalized rat astrocytes (DITNC cells), $\mathrm{cPLA}_{2}$ mediated the $\mathrm{A} \beta$-induced membrane molecular order increase (biophysical parameter which characterizes molecular packing of lipids and water in lipid bilayers) [147]. In primary rat cortical astrocytes, ROS induced by menadione, a redox active agent, also altered astrocyte's membrane molecular order through activation of $\mathrm{CPLA}_{2}$ [148]. $\mathrm{PLA}_{2}$ activation has been shown to affect lipid membrane fluidity and $\mathrm{A} \beta \mathrm{PP}$ processing as well $[149,150]$. In $\mathrm{AD}$ brains, there is evidence for reduced membrane fluidity coupled with decreased PLA 2 activity $[146,151,152]$. Similarly, inhibition of $\mathrm{PLA}_{2}$ activity in rat hippocampus has been shown to reduce membrane fluidity and impair the formation of short- and long-term memory [150, 153]. Arachidonic acid (AA), PLA 2 -hydrolyzed product, increased fluidity of membranes in cultured cerebral endothelial cells $[154,155]$ and hippocampal neurons in vivo [114]. Secretory sPLA $2_{-}^{-}$ III and AA have been shown to increase membrane fluidity and $\mathrm{sA} \beta \mathrm{PP}_{\alpha}$ secretion and decrease levels of $\mathrm{A} \beta_{1-42}$ in $\mathrm{SH}-$ SY5Y cells [156]. Another hydrolyzed product of $\mathrm{PLA}_{2}$, DHA, has also been demonstrated to increase membrane fluidity and $\mathrm{sA} \beta \mathrm{PP}_{\alpha}$ secretion in HEK cells and in neuronal SH-SY5Y overexpressing A $\beta$ PP cells [157]. In addition, it has been reported that nonspecific $\mathrm{PLA}_{2}$ inhibitor partially suppressed muscarinic receptor-stimulated increases in ${ }_{\mathrm{SA}} \beta \mathrm{PP}_{\alpha}$ secretion in SH-SY5Y [23]. Since $\mathrm{PLA}_{2}$ increases membrane fluidity and nonamyloidogenic cleavage of $\mathrm{A} \beta \mathrm{PP}$,
$\mathrm{PLA}_{2}$ activity modulation can be considered as a potential target for AD treatment.

\section{Role of Membrane Physical Properties in A $\beta$ - Membrane Interaction and $\mathrm{A} \beta$ Cytotoxicity}

3.1. A $\beta$-Membrane Interactions Studied in Membrane Models and in Cell Cultures. Cleavage of $\mathrm{A} \beta \mathrm{PP}$ leads to the production of $\mathrm{A} \beta$ peptides of different length, of which $\mathrm{A} \beta_{1-40}$ is the major species and $\mathrm{A} \beta_{1-42}$ is the most fibrillogenic and toxic component in AD plaques [27]. Numerous studies have demonstrated direct interaction of $\mathrm{A} \beta_{1-40}$ and $\mathrm{A} \beta_{1-42}$ with components of the plasma membrane, which consequentially disrupts the membrane properties [28-33, 158160]. There are several suggested types of $A \beta$-membrane interactions. $\mathrm{A} \beta$ peptide can be retained in a membrane upon $\mathrm{A} \beta \mathrm{PP}$ cleavage, thus being prevented against release and aggregation [161]. It also can be released as soluble monomers into the extracellular environment and then be removed $[161,162]$. On the other hand, $\mathrm{A} \beta$ can reinsert into a membrane and form ion-conducting pores or bind to a membrane surface by undergoing accelerated aggregation and form nonspecific structures, which causes thinning and deformation to the membrane [161, 163-166].

$\mathrm{A} \beta_{1-42}$ has been shown to reduce membrane fluidity and accelerate the amyloidogenic processing of $\mathrm{A} \beta \mathrm{PP}[25,33$, 167-172]. In vivo, a decrease in membrane fluidity of synaptosomes isolated from frontal and hypothalamic neurons of 3-month-old mice, administrated with $\mathrm{A} \beta$, has been demonstrated [171]. By using in situ atomic force microscopy and fluorescence spectroscopy, randomly structured $\mathrm{A} \beta_{1-42}$ has been reported to decrease membrane fluidity of planar bilayers composed of total brain lipids, and this effect is cholesterol-content dependent: the most dramatic effect has been seen for cholesterol-enriched samples [168]. DPH (1,6diphenyl-1,3,5-hexatriene) fluorescence study has shown a similar effect of $\mathrm{A} \beta_{1-40}$ on membrane fluidity of unilamellar liposomes with a strong correlation to $\mathrm{A} \beta$ aggregation state and $\mathrm{pH}[170]$. It has been reported that unaggregated peptides and $\mathrm{pH} 7$ do not affect membrane fluidity, while aggregated $\mathrm{A} \beta$ at $\mathrm{pH} 6$ or 7 decreased membrane fluidity in a time- and dose-dependent manner [170]. Studies of SH-SY5Y human neuroblastoma cells have shown some contradictory results. In this observation, $\mathrm{A} \beta_{1-42}$ monomers increased fluidity of cell membranes, and $\mathrm{A} \beta$-Aluminium complex promoted even a greater effect [172]. Differences in effects of $\mathrm{A} \beta$ on fluidity could result from the tissue source and preparation, whether $A \beta$ is soluble or aggregated, and the age of the organism. The differences in effects of $\mathrm{A} \beta$ on fluidity could also be the result of differences in the location of the fluorescent probes in the membrane environment and the lifetime of the fluorescent probes.

The fluorescence microscopy of a membrane with the environmentally sensitive probe Laurdan has demonstrated the ability of $\mathrm{A} \beta_{1-42}$ oligomers to affect the membrane molecular order $[147,173,174]$. It has been shown that an interaction of $\mathrm{A} \beta_{1-42}$ with artificial membranes made them molecularly disordered (more water molecules were 
partitioned into the membrane core) due most likely to the insertion of the peptide into the bilayer and the direct alteration of membrane lipid packing. In the same study, the effect of $A \beta_{1-42}$ oligomers on immortalized rat astrocytes (DITNC cells) membranes was opposite. DITNC membranes become more molecularly ordered upon incubation with $\mathrm{A} \beta$ in a time-dependent manner, and it was consistent with activation of $\mathrm{CPLA}_{2}$. At the same time, in the presence of NADPH oxidase inhibitor, the membranes of the cells remained molecularly disordered. These results suggested an indirect effect of $A \beta$ through the signaling pathway involving NADPH oxidase and $\mathrm{CPLA}_{2}$ [147].

The study of the interaction of $A \beta_{1-42}$ with unilamellar lipid vesicles has demonstrated increased vesicle fusion and a thinning of the lipid bilayer and enhancing of these effects at $\mathrm{pH} 7$ and at a high $\mathrm{A} \beta /$ lipid ratio [175]. The micropipette manipulation of giant unilamellar vesicles has shown the ability of $\mathrm{A} \beta_{1-42}$ to affect the membrane lysis tension depending on artificial membrane lipid composition. It has been found that neither $\mathrm{A} \beta_{1-42}$ nor $\mathrm{A} \beta_{1-40}$ changed mechanical properties of glycerophospholipid-cholesterol vesicles, while partial substitutions of cholesterol with $7 \beta$ hydroxycholesterol that contained additional dipole of oxysterol led to a dramatic reduction of the lysis tension upon $\mathrm{A} \beta$ treatment. The results of this experiment strongly suggest that a negative bilayer surface charge is required for $A \beta$ membrane interaction [176].

The $\mathrm{A} \beta$-membrane interaction may also be followed by the incorporation of $A \beta$ into the membranes and formation of cation-selective channels, which lead to alteration of membrane permeability and electrical conductance [31, 177186]. The study of the effects of soluble $A \beta_{1-42}$ oligomers on planar lipid and tethered lipid bilayers has indicated that $\mathrm{A} \beta$ oligomers were inserted into the hydrophobic core of the bilayer, affecting both membrane leaflets and significantly increasing membrane ion current $[31,178]$. It has been demonstrated that $\mathrm{A} \beta$-induced ion conductance was different from ion transfer through water-filled pores and depended on peptide concentration and membrane lipid composition [178]. Similarly, $\mathrm{A} \beta_{1-40}$ caused a dosedependent increase in the $\mathrm{Na}^{+}, \mathrm{Ca}^{2+}$, and $\mathrm{K}^{+}$influx in the lumen of liposomes formed from the acidic phospholipids but did not change cation conductance in a case of liposomes formed from the neutral phospholipids [179]. There was also evidence that $\mathrm{A} \beta$ induced an increase in membrane conductance, which was dependent on the area compressibility of the lipid bilayer. Membranes with a large area compressibility modulus were almost insensitive to $A \beta_{1-42}$ oligomers, while membranes formed from soft, highly compressible lipids were very sensitive to the presence of oligomers [31].

In vitro, after $\mathrm{A} \beta_{1-42}$ treatment, the membranes of human neuronal hNT cells and neuron-like differentiated PC12 cells depolarized and exhibited enhanced membrane permeability $[183,186]$. Patch-clamp studies of a cell line derived from hypothalamic gonadotrophin-releasing hormone GnRH neurons have demonstrated spontaneous formation of $\mathrm{Zn}^{2+}$-sensitive channel pores upon $\mathrm{A} \beta_{1-40}$ monomers treatment [184]. Similarly, $\mathrm{A} \beta_{1-40}$ aggregates induced perforation of hippocampal neuronal synapses, causing an increase in membrane conductance, intracellular calcium, and ethidium bromide influx [185]. It has been suggested that $\mathrm{A} \beta$-induced membrane depolarization and increased ions influx in neurons was not just due to forming of cation-selective pores but rather was a consequence of events resulting from downstream pathways with involvement of metabotropic glutamate receptor and G-proteins [186].

\subsection{Membrane-Associated Conformational Modifications and} Aggregation of $A \beta$. In a previous section, we discussed the ability of $\mathrm{A} \beta$ to alter biophysical properties of membranes and the dependence of these processes on membrane environment. These studies suggest that membrane property and composition, in turn, play a critical role in conformational changes and aggregation of $A \beta$. The aggregation of $A \beta$ is a complicated multistep process consisting of several phases: monomers $\rightarrow$ soluble oligomers (clusters of small numbers of peptide molecules without a fibrillar structure) $\rightarrow$ protofibrils (aggregates of isolated or clustered spherical beads made up of $\sim 20$ molecules with $\beta$-sheet structure) $\rightarrow$ mature fibrils [187]. Although the mechanism which initiates $\mathrm{A} \beta$ aggregation is not fully understood, it has been shown to be modulated by several factors, including concentrations of monomers and their conformational transitions, sequential changes in the $\mathrm{A} \beta$ primary structure, and interactions with metal ions and membrane molecules $[35,37,40,169]$.

In vitro studies have demonstrated that $\mathrm{A} \beta$ monomers can exist in three major conformation forms: $\alpha$-helix, $\beta$ sheet, or random coil depending on physical properties and chemical composition of the environment $[188,189]$. Since the toxic $A \beta$ mostly consists of $\beta$-sheets, even though the original hydrophobic component of $A \beta$ is a part of a transmembrane $\alpha$-helix of $\mathrm{A} \beta \mathrm{PP}$, the conformational transition of $\mathrm{A} \beta$ from $\alpha$-helix or random coil to $\beta$-sheet is most likely the very first step in the formation of oligomers and fibrils [190]. Multidimensional NMR spectroscopy and circular dichroism (CD) studies have demonstrated that alterations in the membrane structure and biophysics can trigger the conversion of soluble $\alpha$-helical monomeric A $\beta_{1-40}$ into the oligomeric $\beta$-sheet conformation [161, 189]. It has been shown that, in an ordered membrane system, $A \beta$ adopted a single $\alpha$-helical confirmation, while in disordered micelles $\mathrm{A} \beta$ rather adopted soluble $\beta$-sheet oligomeric conformation [189]. At the same time, study of the neutral and negatively charged bilayers showed an increase in $\beta$-sheet content as the negative charge on the lipid membrane increased $[161,191]$.

In situ atomic force microscopy and total internal reflection fluorescence microscopy studies have indicated that the size and the shape of $\mathrm{A} \beta_{1-40}$ and $\mathrm{A} \beta_{1-42}$ aggregates, as well as the kinetics of their formation, depended on the physicochemical nature of the surface $[192,193]$. For example, on hydrophilic surfaces (mica) $\mathrm{A} \beta_{1-42}$ formed particulate, pseudomicellar aggregates, while on hydrophobic surfaces (graphite) $\mathrm{A} \beta$ formed uniform, elongated sheets with dimensions consistent with the dimensions of $\beta$-sheets. The results of this study suggested that $\mathrm{A} \beta$ fibril formation may be driven by interactions at the interface of aqueous 
solutions and hydrophobic substrates, which occurs in membranes and lipoprotein particles in vivo [192]. Similarly, $\mathrm{A} \beta_{1-40}$ fibril growth was especially prominent on chemically modified negatively charged quartz surfaces, while no fibril formation was observed on the positively charged surfaces [193].

Numerous in vitro and in vivo studies have demonstrated that lipid bilayer composition, as well as membraneassociated proteins, can regulate $\mathrm{A} \beta$ aggregation in both enhancement and inhibition manner [37-40]. It has been suggested that binding of $\mathrm{A} \beta$ to the ganglioside-containing membranes can induce a structural transition from random coil to $\beta$-sheet in $\mathrm{A} \beta 40 / 42$ and accelerate fibril formation [194-196]. Electron microscopy studies have demonstrated that interaction of $\mathrm{A} \beta 40 / 42$ with plasma, lysosomal, and endosomal membranes accelerated fibrillogenesis of $\mathrm{A} \beta$, while the presence of Golgi membranes hindered the process [169].

\section{Conclusion}

An increasing amount of evidence demonstrates that a lot of cellular processes in $\mathrm{AD}$ are intimately associated with physical properties and organization of membranes. The primary step in $\mathrm{A} \beta$ accumulation, the amyloidogenic cleavage of $\mathrm{A} \beta \mathrm{PP}$, is affected by the membrane properties such as membrane fluidity and molecular order and can be modulated by removal of cholesterol and manipulation of membrane lipid composition. $\mathrm{A} \beta$-membranes interaction, in turn, affects biophysical membrane properties and accelerates the amyloidogenic processing of $\mathrm{A} \beta \mathrm{PP}$. $\mathrm{A} \beta$ has been reported to reduce membrane fluidity, affect molecular order and membrane lysis tension, induce thinning of the lipid bilayer, and increase membrane conductance. $\mathrm{A} \beta$ can also indirectly affect membrane properties by binding to membrane receptors and triggering downstream signaling pathways leading to oxidative stress and inflammation. On the other hand, the ability of $\mathrm{A} \beta$ to interact with membranes of neurons and other cerebral cells depends on physical properties and organization of membranes, such as cholesterol content, lipid composition and A $\beta /$ lipid ratio, $\mathrm{pH}$, the presence of metal ions, and bilayer surface charge. Membrane properties and composition play critical roles in $\mathrm{A} \beta$ cytotoxicity associated with its conformational changes and aggregation state as well. Therefore, understanding how membrane properties and organization are related to cellular pathways in $\mathrm{AD}$ should prove to provide insights into the mechanisms of the pathogenesis in AD.

\section{References}

[1] D. W. Dickson, "Microglia in Alzheimer's disease and transgenic models: how close the fit?" American Journal of Pathology, vol. 154, no. 6, pp. 1627-1631, 1999.

[2] S. A. Frautschy, F. Yang, M. Irrizarry et al., "Microglial response to amyloid plaques in APPsw transgenic mice," American Journal of Pathology, vol. 152, no. 1, pp. 307-317, 1998.
[3] P. L. McGeer, S. Itagaki, H. Tago, and E. G. McGeer, "Reactive microglia in patients with senile dementia of the Alzheimer type are positive for the histocompatibility glycoprotein HLA-DR," Neuroscience Letters, vol. 79, no. 1-2, pp. 195-200, 1987.

[4] L. S. Perlmutter, E. Barron, and H. C. Chui, "Morphologic association between microglia and senile plaque amyloid in Alzheimer's disease," Neuroscience Letters, vol. 119, no. 1, pp. 32-36, 1990.

[5] D. J. Selkoe, "The origins of Alzheimer disease: a is for amyloid," Journal of the American Medical Association, vol. 283, no. 12, pp. 1615-1617, 2000.

[6] M. Stalder, A. Phinney, A. Probst, B. Sommer, M. Staufenbiel, and M. Jucker, "Association of microglia with amyloid plaques in brains of APP23 transgenic mice," American Journal of Pathology, vol. 154, no. 6, pp. 1673-1684, 1999.

[7] R. Vassar, "BACE1: the $\beta$-secreiase enzyme in Alzheimer's disease," Journal of Molecular Neuroscience, vol. 23, no. 1-2, pp. 105-113, 2004.

[8] E. Thornton, R. Vink, P. C. Blumbergs, and C. Van Den Heuvel, "Soluble amyloid precursor protein $\alpha$ reduces neuronal injury and improves functional outcome following diffuse traumatic brain injury in rats," Brain Research, vol. 1094, no. 1, pp. 38-46, 2006.

[9] H. Cheng, K. S. Vetrivel, P. Gong, X. Meckler, A. Parent, and G. Thinakaran, "Mechanisms of disease: new therapeutic strategies for Alzheimer's disease-targeting APP processing in lipid rafts," Nature Clinical Practice Neurology, vol. 3, no. 7, pp. 374-382, 2007.

[10] C. Haass, A. Y. Hung, M. G. Schlossmacher, D. B. Teplow, and D. J. Selkoe, " $\beta$-Amyloid peptide and a 3-kDa fragment are derived by distinct cellular mechanisms," The Journal of Biological Chemistry, vol. 268, no. 5, pp. 3021-3024, 1993.

[11] E. H. Koo and S. L. Squazzo, "Evidence that production and release of amyloid $\beta$-protein involves the endocytic pathway," The Journal of Biological Chemistry, vol. 269, no. 26, pp. 17386-17389, 1994.

[12] J. M. Cordy, I. Hussain, C. Dingwall, N. M. Hooper, and A. J. Turner, "Exclusively targeting $\beta$-secretase to lipid rafts by GPI-anchor addition up-regulates $\beta$-site processing of the amyloid precursor protein," Proceedings of the National Academy of Sciences of the United States of America, vol. 100, no. 20, pp. 11735-11740, 2003.

[13] R. Ehehalt, P. Keller, C. Haass, C. Thiele, and K. Simons, "Amyloidogenic processing of the Alzheimer $\beta$-amyloid precursor protein depends on lipid rafts," Journal of Cell Biology, vol. 160, no. 1, pp. 113-123, 2003.

[14] C. Kaether and C. Haass, "A lipid boundary separates APP and secretases and limits amyloid $\beta$-peptide generation," Journal of Cell Biology, vol. 167, no. 5, pp. 809-812, 2004.

[15] L. Marlow, M. Cain, M. A. Pappolla, and K. Sambamurti, " $\beta$-Secretase Processing of the Alzheimer's Amyloid Protein Precursor (APP)," Journal of Molecular Neuroscience, vol. 20, no. 3, pp. 233-239, 2003.

[16] H. Tun, L. Marlow, I. Pinnix, R. Kinsey, and K. Sambamurti, "Lipid rafts play an important role in $\mathrm{A} \beta$ biogenesis by regulating the $\beta$-secretase pathway," Journal of Molecular Neuroscience, vol. 19, no. 1-2, pp. 31-35, 2002.

[17] K. S. Vetrivel, H. Cheng, W. Lin et al., "Association of $\gamma$-secretase with lipid rafts in post-golgi and endosome membranes," The Journal of Biological Chemistry, vol. 279, no. 43, pp. 44945-44954, 2004. 
[18] P. C. Reid, Y. Urano, T. Kodama, and T. Hamakubo, "Alzheimer's disease: cholesterol, membrane rafts, isoprenoids and statins," Journal of Cellular and Molecular Medicine, vol. 11, no. 3, pp. 383-392, 2007.

[19] E. Kojro, G. Gimpl, S. Lammich, W. März, and F. Fahrenholz, "Low cholesterol stimulates the nonamyloidogenic pathway by its effect on the $\alpha$-secretase ADAM 10," Proceedings of the National Academy of Sciences of the United States of America, vol. 98, no. 10, pp. 5815-5820, 2001.

[20] N. Sawamura, M. Ko, W. Yu et al., "Modulation of amyloid precursor protein cleavage by cellular sphingolipids," The Journal of Biological Chemistry, vol. 279, no. 12, pp. 11984 11991, 2004.

[21] M. Simons, P. Keller, B. De Strooper, K. Beyreuther, C. G. Dotti, and K. Simons, "Cholesterol depletion inhibits the generation of $\beta$-amyloid in hippocampal neurons," Proceedings of the National Academy of Sciences of the United States of America, vol. 95, no. 11, pp. 6460-6464, 1998.

[22] C. A. F. Arnim, B. von Einem, P. Weber et al., "Impact of cholesterol level upon APP and BACE proximity and APP cleavage," Biochemical and Biophysical Research Communications, vol. 370, no. 2, pp. 207-212, 2008.

[23] H. W. Cho, J. H. Kim, S. Choi, and H. J. Kim, "Phospholipase A2 is involved in muscarinic receptor-mediated $\operatorname{sAPP} \alpha$ release independently of cyclooxygenase or lypoxygenase activity in SH-SY5Y cells," Neuroscience Letters, vol. 397, no. 3, pp. 214-218, 2006.

[24] A. B. Clement, G. Gimpl, and C. Behl, "Oxidative stress resistance in hippocampal cells is associated with altered membrane fluidity and enhanced nonamyloidogenic cleavage of endogenous amyloid precursor protein," Free Radical Biology and Medicine, vol. 48, no. 9, pp. 1236-1241, 2010.

[25] I. Peters, U. Igbavboa, T. Schütt et al., "The interaction of beta-amyloid protein with cellular membranes stimulates its own production," Biochimica et Biophysica Acta, vol. 1788, no. 5, pp. 964-972, 2009.

[26] G. P. Eckert, S. Chang, J. Eckmann et al., "Liposomeincorporated DHA increases neuronal survival by enhancing non-amyloidogenic APP processing," Biochimica et Biophysica Acta, vol. 1808, no. 1, pp. 236-243, 2011.

[27] S. L. Bernstein, T. Wyttenbach, A. Baumketner et al., "Amyloid $\beta$-protein: monomer structure and early aggregation states of A $\beta 42$ and its Pro alloform," Journal of the American Chemical Society, vol. 127, no. 7, pp. 2075-2084, 2005.

[28] R. Friedman, R. Pellarin, and A. Caflisch, "Amyloid Aggregation on Lipid Bilayers and Its Impact on Membrane Permeability," Journal of Molecular Biology, vol. 387, no. 2, pp. 407-415, 2009.

[29] A. Kakio, S. I. Nishimoto, K. Yanagisawa, Y. Kozutsumi, and K. Matsuzaki, "Interactions of amyloid $\beta$-protein with various gangliosides in raft-like membranes: importance of GM1 ganglioside-bound form as an endogenous seed for Alzheimer amyloid," Biochemistry, vol. 41, no. 23, pp. 73857390, 2002.

[30] E. Terzi, G. Hölzemann, and J. Seelig, "Interaction of Alzheimer $\beta$-amyloid peptide(1-40) with lipid membranes," Biochemistry, vol. 36, no. 48, pp. 14845-14852, 1997.

[31] Y. Sokolov, J. A. Kozak, R. Kayed, A. Chanturiya, C. Glabe, and J. E. Hall, "Soluble amyloid oligomers increase bilayer conductance by altering dielectric structure," Journal of General Physiology, vol. 128, no. 6, pp. 637-647, 2006.

[32] A. Buchsteiner, T. Hauß, S. Dante, and N. A. Dencher, "Alzheimer's disease amyloid- $\beta$ peptide analogue alters the ps-dynamics of phospholipid membranes," Biochimica et Biophysica Acta, vol. 1798, no. 10, pp. 1969-1976, 2010.

[33] G. P. Eckert, W. G. Wood, and W. E. Müller, "Lipid membranes and $\beta$-amyloid: a harmful connection," Current Protein and Peptide Science, vol. 11, no. 5, pp. 319-325, 2010.

[34] P. T. Wong, J. A. Schauerte, K. C. Wisser et al., "Amyloid$\beta$ membrane binding and permeabilization are distinct processes influenced separately by membrane charge and fluidity," Journal of Molecular Biology, vol. 386, no. 1, pp. 8196, 2009.

[35] T. L. Lau, E. E. Ambroggio, D. J. Tew et al., "Amyloid- $\beta$ peptide disruption of lipid membranes and the effect of metal ions," Journal of Molecular Biology, vol. 356, no. 3, pp. 759770, 2006.

[36] T. L. Lau, J. D. Gehman, J. D. Wade et al., "Membrane interactions and the effect of metal ions of the amyloidogenic fragment $\mathrm{A} \beta(25-35)$ in comparison to $\mathrm{A} \beta(1-42)$," Biochimica et Biophysica Acta, vol. 1768, no. 10, pp. 2400-2408, 2007.

[37] J. McLaurin, D. S. Yang, C. M. Yip, and P. E. Fraser, "Review: modulating factors in amyloid- $\beta$ fibril formation," Journal of Structural Biology, vol. 130, no. 2-3, pp. 259-270, 2000.

[38] M. Vestergaard, T. Hamada, and M. Takagi, "Using model membranes for the study of amyloid beta:lipid interactions and neurotoxicity," Biotechnology and Bioengineering, vol. 99, no. 4, pp. 753-763, 2008.

[39] K. Matsuzaki, "Physicochemical interactions of amyloid $\beta$ peptide with lipid bilayers," Biochimica et Biophysica Acta, vol. 1768, no. 8, pp. 1935-1942, 2007.

[40] Y. Verdier, M. Zarándi, and B. Penke, "Amyloid $\beta$-peptide interactions with neuronal and glial cell plasma membrane: binding sites and implications for Alzheimer's disease," Journal of Peptide Science, vol. 10, no. 5, pp. 229-248, 2004.

[41] G. P. Eckert, "Manipulation of lipid rafts in neuronal cells," The Open Biology Journal, vol. 3, pp. 1874-1967, 2010.

[42] U. Igbavboa, N. A. Avdulov, F. Schroeder, and W. G. Wood, "Increasing age alters transbilayer fluidity and cholesterol asymmetry in synaptic plasma membranes of mice," Journal of Neurochemistry, vol. 66, no. 4, pp. 1717-1725, 1996.

[43] Y. Barenholz, "Sphingomyelin and cholesterol: from membrane biophysics and rafts to potential medical applications," Sub-cellular Biochemistry, vol. 37, pp. 167-215, 2004.

[44] W. G. Wood, F. Schroeder, U. Igbavboa, N. A. Avdulov, and S. V. Chochina, "Brain membrane cholesterol domains, aging and amyloid beta-peptides," Neurobiology of Aging, vol. 23, no. 5, pp. 685-694, 2002.

[45] D. Arrais and J. Martins, "Bilayer polarity and its thermal dependency in the $l_{0}$ and $l_{\mathrm{d}}$ phases of binary phosphatidylcholine/cholesterol mixtures," Biochimica et Biophysica Acta, vol. 1768, no. 11, pp. 2914-2922, 2007.

[46] Q. Chen, J. Amaral, P. Biancani, and J. Behar, "Excess membrane cholesterol alters human gallbladder muscle contractility and membrane fluidity," Gastroenterology, vol. 116, no. 3, pp. 678-685, 1999.

[47] K. K. Halling, B. Ramstedt, and J. P. Slotte, "Glycosylation induces shifts in the lateral distribution of cholesterol from ordered towards less ordered domains," Biochimica et Biophysica Acta, vol. 1778, no. 4, pp. 1100-1111, 2008.

[48] D. Dumas, V. Latger, M. L. Viriot, W. Blondel, and J. F. Stoltz, "Membrane fluidity and oxygen diffusion in cholesterolenriche endothelial cells," Clinical Hemorheology and Microcirculation, vol. 21, no. 3-4, pp. 255-261, 1999.

[49] C. Socaciu, R. Jessel, and H. A. Diehl, "Competitive carotenoid and cholesterol incorporation into liposomes: 
effects on membrane phase transition, fluidity, polarity and anisotropy," Chemistry and Physics of Lipids, vol. 106, no. 1, pp. 79-88, 2000.

[50] D. Wang and B. G. Schreurs, "Dietary cholesterol modulates the excitability of rabbit hippocampal CA1 pyramidal neurons," Neuroscience Letters, vol. 479, no. 3, pp. 327-331, 2010.

[51] M. Hao, S. Mukherjee, Y. Sun, and F. R. Maxfield, "Effects of cholesterol depletion and increased lipid unsaturation on the properties of endocytic membranes," The Journal of Biological Chemistry, vol. 279, no. 14, pp. 14171-14178, 2004.

[52] M. P. Burns and G. W. Rebeck, "Intracellular cholesterol homeostasis and amyloid precursor protein processing," Biochimica et Biophysica Acta, vol. 1801, no. 8, pp. 853-859, 2010.

[53] G. P. Eckert, C. Kirsch, and W. E. Müller, "Brain-membrane cholesterol in Alzheimer's disease," Journal of Nutrition, Health and Aging, vol. 7, no. 1, pp. 18-23, 2003.

[54] M. Kosicek, M. Malnar, A. Goate, and S. Hecimovic, "Cholesterol accumulation in Niemann Pick type C (NPC) model cells causes a shift in APP localization to lipid rafts," Biochemical and Biophysical Research Communications, vol. 393, no. 3, pp. 404-409, 2010.

[55] J. Xiu, A. Nordberg, X. Qi, and Z.-Z. Guan, "Influence of cholesterol and lovastatin on $\alpha$-form of secreted amyloid precursor protein and expression of $\alpha 7$ nicotinic receptor on astrocytes," Neurochemistry International, vol. 49, no. 5, pp. 459-465, 2006.

[56] J. L. Galbete, T. R. Martin, E. Peressini, P. Modena, R. Bianchi, and G. Forloni, "Cholesterol decreases secretion of the secreted form of amyloid precursor protein by interfering with glycosylation in the protein secretory pathway," Biochemical Journal, vol. 348, no. 2, pp. 307-313, 2000.

[57] M. Racchi, R. Baetta, N. Salvietti et al., "Secretory processing of amyloid precursor protein is inhibited by increase in cellular cholesterol content," Biochemical Journal, vol. 322, no. 3, pp. 893-898, 1997.

[58] W. W. Liu, S. Todd, D. T. R. Coulson et al., "A novel reciprocal and biphasic relationship between membrane cholesterol and $\beta$-secretase activity in SH-SY5Y cells and in human platelets," Journal of Neurochemistry, vol. 108, no. 2, pp. 341-349, 2009.

[59] W. Davis, "The cholesterol transport inhibitor U18666a regulates amyloid precursor protein metabolism and trafficking in N2aAPP "swedish" cells," Current Alzheimer Research, vol. 5, no. 5, pp. 448-456, 2008.

[60] H. Runz, J. Rietdorf, I. Tomic et al., "Inhibition of intracellular cholesterol transport alters presenilin localization and amyloid precursor protein processing in neuronal cells," Journal of Neuroscience, vol. 22, no. 5, pp. 1679-1689, 2002.

[61] H. J. Huttunen, C. Peach, R. Bhattacharyya et al., "Inhibition of acyl-coenzyme A: cholesterol acyl transferase modulates amyloid precursor protein trafficking in the early secretory pathway," FASEB Journal, vol. 23, no. 11, pp. 3819-3828, 2009.

[62] H. J. Huttunen, D. Havas, C. Peach et al., "The Acylcoenzyme a: cholesterol acyltransferase inhibitor ci-1011 reverses diffuse brain amyloid pathology in aged amyloid precursor protein transgenic mice," Journal of Neuropathology and Experimental Neurology, vol. 69, no. 8, pp. 777-788, 2010.

[63] L. Puglielli, B. C. Ellis, L. A. Mackenzie Ingano, and D. M. Kovacs, "Role of acyl-coenzyme A: cholesterol acyltransferase activity in the processing of the amyloid precursor protein," Journal of Molecular Neuroscience, vol. 24, no. 1, pp. 93-96, 2004.
[64] K. Fassbender, M. Simons, C. Bergmann et al., "Simvastatin strongly reduces levels of Alzheimer's disease $\beta$-amyloid peptides A $\beta 42$ and $\mathrm{A} \beta 40$ in vitro and in vivo," Proceedings of the National Academy of Sciences of the United States of America, vol. 98, no. 10, pp. 5856-5861, 2001.

[65] J. Abad-Rodriguez, M. D. Ledesma, K. Craessaerts et al., "Neuronal membrane cholesterol loss enhances amyloid peptide generation," Journal of Cell Biology, vol. 167, no. 5, pp. 953-960, 2004.

[66] O. G. Luneva, N. A. Brazhe, N. V. Maksimova et al., "Ion transport, membrane fluidity and haemoglobin conformation in erythrocyte from patients with cardiovascular diseases: role of augmented plasma cholesterol," Pathophysiology, vol. 14, no. 1, pp. 41-46, 2007.

[67] M. M. Gleason, M. S. Medow, and T. N. Tulenko, "Excess membrane cholesterol alters calcium movements, cytosolic calcium levels, and membrane fluidity in arterial smooth muscle cells," Circulation Research, vol. 69, no. 1, pp. 216227, 1991.

[68] A. Colell, C. García-Ruiz, J. M. Lluis, O. Coll, M. Mari, and J. C. Fernández-Checa, "Cholesterol impairs the adenine nucleotide translocator-mediated mitochondrial permeability transition through altered membrane fluidity," The Journal of Biological Chemistry, vol. 278, no. 36, pp. 33928-33935, 2003.

[69] T. Róg, L. M. Stimson, M. Pasenkiewicz-Gierula, I. Vattulainen, and M. Karttunen, "Replacing the cholesterol hydroxyl group with the ketone group facilitates sterol flipflop and promotes membrane fluidity," Journal of Physical Chemistry B, vol. 112, no. 7, pp. 1946-1952, 2008.

[70] M. G. Buffone, S. V. Verstraeten, J. C. Calamera, and G. F. Doncel, "High cholesterol content and decreased membrane fluidity in human spermatozoa are associated with protein tyrosine phosphorylation and functional deficiencies," Journal of Andrology, vol. 30, no. 5, pp. 552-558, 2009.

[71] M. Hashimoto, S. Hossain, and O. Shido, "Docosahexaenoic acid but not eicosapentaenoic acid withstands dietary cholesterol-induced decreases in platelet membrane fluidity," Molecular and Cellular Biochemistry, vol. 293, no. 1-2, pp. 18, 2006.

[72] S. Bodovitz and W. L. Klein, "Cholesterol modulates $\alpha$ secretase cleavage of amyloid precursor protein," The Journal of Biological Chemistry, vol. 271, no. 8, pp. 4436-4440, 1996.

[73] J. R. Cirrito, J. E. Kang, J. Lee et al., "Endocytosis is required for synaptic activity-dependent release of amyloid- $\beta$ in vivo," Neuron, vol. 58, no. 1, pp. 42-51, 2008.

[74] A. Kinoshita, H. Fukumoto, T. Shah, C. M. Whelan, M. C. Irizarry, and B. T. Hyman, "Demonstration by FRET of BACE interaction with the amyloid precursor protein at the cell surface and in early endosomes," Journal of Cell Science, vol. 116, no. 16, pp. 3339-3346, 2003.

[75] L. Rajendran, A. Schneider, G. Schlechtingen et al., "Efficient inhibition of the Alzheimer's disease $\beta$-secretase by membrane targeting," Science, vol. 320, no. 5875, pp. 520-523, 2008.

[76] S. Schöbel, S. Neumann, M. Hertweck et al., "A novel sorting nexin modulates endocytic trafficking and $\alpha$-secretase cleavage of the amyloid precursor protein," The Journal of Biological Chemistry, vol. 283, no. 21, pp. 14257-14268, 2008.

[77] S. A. Small and S. Gandy, "Sorting through the cell biology of Alzheimer's disease: intracellular pathways to pathogenesis," Neuron, vol. 52, no. 1, pp. 15-31, 2006.

[78] O. M. Grbovic, P. M. Mathews, Y. Jiang et al., "Rab5stimulated up-regulation of the endocytic pathway increases 
intracellular $\beta$-cleaved amyloid precursor protein carboxylterminal fragment levels and $\mathrm{A} \beta$ production," The Journal of Biological Chemistry, vol. 278, no. 33, pp. 31261-31268, 2003.

[79] J. C. Cossec, A. Simon, C. Marquer et al., "Clathrindependent APP endocytosis and A $\beta$ secretion are highly sensitive to the level of plasma membrane cholesterol," Biochimica et Biophysica Acta, vol. 1801, no. 8, pp. 846-852, 2010.

[80] J. P. Schuchardt, M. Huss, M. Stauss-Grabo, and A. Hahn, "Significance of long-chain polyunsaturated fatty acids (PUFAs) for the development and behaviour of children," European Journal of Pediatrics, vol. 169, no. 2, pp. 149-164, 2010.

[81] C. K. Chow, Ed., Fatty Acids in Foods and Their Health Implications, Taylor \& Francis, Boca Raton, Fla, USA, 2007.

[82] W. E. Connor, "Importance of n-3 fatty acids in health and disease," American Journal of Clinical Nutrition, vol. 71, no. 1, pp. 171S-175S, 2000.

[83] S. C. Dyall and A. T. Michael-Titus, "Neurological benefits of omega-3 fatty acids," NeuroMolecular Medicine, vol. 10, no. 4, pp. 219-235, 2008.

[84] N. G. Bazan and B. L. Scott, "Dietary omega-3 fatty acids and accumulation of docosahexaenoic acid in rod photoreceptor cells of the retina and at synapses," Upsala Journal of Medical Sciences, Supplement, no. 48, pp. 97-107, 1990.

[85] R. T. Holman, S. B. Johnson, and P. L. Ogburn, "Deficiency of essential fatty acids and membrane fluidity during pregnancy and lactation," Proceedings of the National Academy of Sciences of the United States of America, vol. 88, no. 11, pp. 4835-4839, 1991.

[86] R. Uauy, D. R. Hoffman, P. Peirano, D. G. Birch, and E. E. Birch, "Essential fatty acids in visual and brain development," Lipids, vol. 36, no. 9, pp. 885-895, 2001.

[87] J. M. Alessandri, P. Guesnet, S. Vancassel et al., "Polyunsaturated fatty acids in the central nervous system: evolution of concepts and nutritional implications throughout life," Reproduction Nutrition Development, vol. 44, no. 6, pp. 509538,2004

[88] I. Carrié, G. Abellan Van Kan, Y. Rolland, S. GilletteGuyonnet, and B. Vellas, "PUFA for prevention and treatment of dementia?" Current Pharmaceutical Design, vol. 15, no. 36, pp. 4173-4185, 2009.

[89] L. A. Horrocks and A. A. Farooqui, "Docosahexaenoic acid in the diet: its importance in maintenance and restoration of neural membrane function," Prostaglandins Leukotrienes and Essential Fatty Acids, vol. 70, no. 4, pp. 361-372, 2004.

[90] S. C. Heinrichs, "Dietary $\omega-3$ fatty acid supplementation for optimizing neuronal structure and function," Molecular Nutrition and Food Research, vol. 54, no. 4, pp. 447-456, 2010.

[91] W. A. Khan, G. C. Blobe, and Y. A. Hannun, "Arachidonic acid and free fatty acids as second messengers and the role of protein kinase C," Cellular Signalling, vol. 7, no. 3, pp. 171184, 1995.

[92] L. Zhou and A. Nilsson, "Sources of eicosanoid precursor fatty acid pools in tissues," Journal of Lipid Research, vol. 42, no. 10, pp. 1521-1542, 2001.

[93] A. J. Sinclair, D. Begg, M. Mathai, and R. S. Weisinger, "Omega 3 fatty acids and the brain: review of studies in depression," Asia Pacific Journal of Clinical Nutrition, vol. 16, no. 1, supplement, pp. 391-397, 2007.

[94] J. R. Hibbeln, J. C. Umhau, D. T. George, S. E. Shoaf, M. Linnoila, and N. Salem Jr., "Plasma total cholesterol concentrations do not predict cerebrospinal fluid neurotransmitter metabolites: Implications for the biophysical role of highly unsaturated fatty acids," American Journal of Clinical Nutrition, vol. 71, no. 1, supplement, pp. 331S-338S, 2000.

[95] S. I. Rapoport, "Arachidonic acid and the brain," Journal of Nutrition, vol. 138, no. 12, pp. 2515-2520, 2008.

[96] A. M. Tully, H. M. Roche, R. Doyle et al., "Low serum cholesteryl ester-docosahexaenoic acid levels in Alzheimer's disease: a case-control study," British Journal of Nutrition, vol. 89, no. 4, pp. 483-489, 2003.

[97] E. J. Schaefer, V. Bongard, A. S. Beiser et al., "Plasma phosphatidylcholine docosahexaenoic acid content and risk of dementia and alzheimer disease: the framingham heart study," Archives of Neurology, vol. 63, no. 11, pp. 1545-1550, 2006.

[98] F. Calon, G. P. Lim, T. Morihara et al., "Dietary n-3 polyunsaturated fatty acid depletion activates caspases and decreases NMDA receptors in the brain of a transgenic mouse model of Alzheimer's disease," European Journal of Neuroscience, vol. 22, no. 3, pp. 617-626, 2005.

[99] Q. L. Ma, F. Yang, E. R. Rosario et al., “ $\beta$-Amyloid oligomers induce phosphorylation of tau and inactivation of insulin receptor substrate via c-Jun $\mathrm{N}$-terminal kinase signaling: suppression by omega-3 fatty acids and curcumin," Journal of Neuroscience, vol. 29, no. 28, pp. 9078-9089, 2009.

[100] E. Rogaeva, Y. Meng, J. H. Lee et al., "The neuronal sortilin-related receptor SORL1 is genetically associated with Alzheimer disease," Nature Genetics, vol. 39, no. 2, pp. 168177, 2007.

[101] Q. L. Ma, B. Teter, O. J. Ubeda et al., "Omega-3 fatty acid docosahexaenoic acid increases SorLA/LR11, a sorting protein with reduced expression in sporadic Alzheimer's disease (AD): relevance to AD prevention," Journal of Neuroscience, vol. 27, no. 52, pp. 14299-14307, 2007.

[102] C. R. Hooijmans, C. E. E. M. Van der Zee, P. J. Dederen et al., "DHA and cholesterol containing diets influence Alzheimer-like pathology, cognition and cerebral vasculature in APP/PS1 mice," Neurobiology of Disease, vol. 33, no. 3, pp. 482-498, 2009.

[103] S. Pepe, "Dietary polyunsaturated fatty acids and age-related membrane changes in the heart," Annals of the New York Academy of Sciences, vol. 1114, pp. 381-388, 2007.

[104] S. R. Shaikh and M. Edidin, "Polyunsaturated fatty acids, membrane organization, T cells, and antigen presentation," American Journal of Clinical Nutrition, vol. 84, no. 6, pp. 1277-1289, 2006.

[105] S. R. Shaikh and M. Edidin, "Polyunsaturated fatty acids and membrane organization: elucidating mechanisms to balance immunotherapy and susceptibility to infection," Chemistry and Physics of Lipids, vol. 153, no. 1, pp. 24-33, 2008.

[106] S. Yehuda, S. Rabinovitz, R. L. Carasso, and D. I. Mostofsky, "The role of polyunsaturated fatty acids in restoring the aging neuronal membrane," Neurobiology of Aging, vol. 23, no. 5, pp. 843-853, 2002.

[107] W. Stillwell, S. R. Shaikh, M. Zerouga, R. Siddiqui, and S. R. Wassal, "Docosahexaenoic acid affects cell signaling by altering lipid rafts," Reproduction Nutrition Development, vol. 45, no. 5, pp. 559-579, 2005.

[108] B. Aricha, I. Fishov, Z. Cohen et al., "Differences in membrane fluidity and fatty acid composition between phenotypic variants of Streptococcus pneumoniae," Journal of Bacteriology, vol. 186, no. 14, pp. 4638-4644, 2004. 
[109] A. A. Cader, D. A. Butterfield, B. A. Watkins, B. H. Chung, and B. Hennig, "Electron spin resonance studies of fatty acid-induced alterations in membrane fluidity in cultured endothelial cells," International Journal of Biochemistry and Cell Biology, vol. 27, no. 7, pp. 665-673, 1995.

[110] S. Kitagawa, K. Kotani, and F. Kametani, "Inhibitory mechanism of cis-polyunsaturated fatty acids on platelet aggregation: the relation with their effects on $\mathrm{Ca}^{2+}$ mobilization, cyclic AMP levels and membrane fluidity," Biochimica et Biophysica Acta, vol. 1054, no. 1, pp. 114-118, 1990.

[111] N. Loffhagen, C. Härtig, and W. Babel, "Pseudomonas putida NCTC 10936 balances membrane fluidity in response to physical and chemical stress by changing the saturation degree and the Trans/cis ratio of fatty acids," Bioscience, Biotechnology and Biochemistry, vol. 68, no. 2, pp. 317-323, 2004.

[112] I. B. Zavodnik, A. Zaborowski, A. Niekurzak, and M. Bryszewska, "Effect of free fatty acids on erythrocyte morphology and membrane fluidity," Biochemistry and Molecular Biology International, vol. 42, no. 1, pp. 123-133, 1997.

[113] X. Yang, W. Sheng, G. Y. Sun, and J. C.-M. Lee, "Effects of fatty acid unsaturation numbers on membrane fluidity and $\alpha$-secretase-dependent amyloid precursor protein processing," Neurochemistry International, vol. 58, no. 3, pp. 321$329,2011$.

[114] T. Fukaya, T. Gondaira, Y. Kashiyae et al., "Arachidonic acid preserves hippocampal neuron membrane fluidity in senescent rats," Neurobiology of Aging, vol. 28, no. 8, pp. 1179-1186, 2007.

[115] A. M. Dorrance, D. Graham, A. Dominiczak, and R. Fraser, "Inhibition of nitric oxide synthesis increases erythrocyte membrane fluidity and unsaturated fatty acid content," American Journal of Hypertension, vol. 13, no. 11, pp. 11941202, 2000.

[116] P. C. Calder, P. Yaqoob, D. J. Harvey, A. Watts, and E. A. Newsholme, "Incorporation of fatty acids by concanavalin A-stimulated lymphocytes and the effect on fatty acid composition and membrane fluidity," Biochemical Journal, vol. 300, no. 2, pp. 509-518, 1994.

[117] W. Stillwell and S. R. Wassall, "Docosahexaenoic acid: membrane properties of a unique fatty acid," Chemistry and Physics of Lipids, vol. 126, no. 1, pp. 1-27, 2003.

[118] H. Suzuki, S. J. Park, M. Tamura, and S. Ando, "Effect of the long-term feeding of dietary lipids on the learning ability, fatty acid composition of brain stem phospholipids and synaptic membrane fluidity in adult mice: a comparison of sardine oil diet with palm oil diet," Mechanisms of Ageing and Development, vol. 101, pp. 119-128, 1998.

[119] M. Oksman, H. Iivonen, E. Hogyes et al., "Impact of different saturated fatty acid, polyunsaturated fatty acid and cholesterol containing diets on beta-amyloid accumulation in APP/PS1 transgenic mice," Neurobiology of Disease, vol. 23, no. 3, pp. 563-572, 2006.

[120] C. R. Hooijmans, F. Rutters, P. J. Dederen et al., "Changes in cerebral blood volume and amyloid pathology in aged Alzheimer APP/PS1 mice on a docosahexaenoic acid (DHA) diet or cholesterol enriched Typical Western Diet (TWD)," Neurobiology of Disease, vol. 28, no. 1, pp. 16-29, 2007.

[121] G. P. Lim, F. Calon, T. Morihara et al., "A diet enriched with the omega-3 fatty acid docosahexaenoic acid reduces amyloid burden in an aged Alzheimer mouse model," Journal of Neuroscience, vol. 25, no. 12, pp. 3032-3040, 2005.

[122] C. Sahlin, F. E. Pettersson, L. N. G. Nilsson, L. Lannfelt, and A.-S. Johansson, "Docosahexaenoic acid stimulates non-amyloidogenic APP processing resulting in reduced $\mathrm{A} \beta$ levels in cellular models of Alzheimer's disease," European Journal of Neuroscience, vol. 26, no. 4, pp. 882-889, 2007.

[123] Y. Liu, L. Yang, K. Conde-Knape, D. Beher, M. S. Shearman, and N. S. Shachter, "Fatty acids increase presenilin-1 levels and $\gamma$-secretase activity in PSwt-1 cells," Journal of Lipid Research, vol. 45, no. 12, pp. 2368-2376, 2004.

[124] D. Stephenson, K. Rash, B. Smalstig et al., "Cytosolic phospholipase A is induced in reactive glia following different forms of neurodegeneration," Glia, vol. 27, no. 2, pp. 110$128,1999$.

[125] D. T. Stephenson, C. A. Lemere, D. J. Selkoe, and J. A. Clemens, "Cytosolic phospholipase A (cPLA) immunoreactivity is elevated in Alzheimer's disease brain," Neurobiology of Disease, vol. 3, no. 1, pp. 51-63, 1996.

[126] G. S. D. Moses, M. D. Jensen, L. F. Lue et al., "Secretory PLA-IIA: a new inflammatory factor for Alzheimer's disease," Journal of Neuroinflammation, vol. 3, article 28, 2006.

[127] R. M. Adibhatla and J. F. Hatcher, "Phospholipase A, reactive oxygen species, and lipid peroxidation in cerebral ischemia," Free Radical Biology and Medicine, vol. 40, no. 3, pp. 376-387, 2006.

[128] A. A. Farooqui, W.-Y. Ong, and L. A. Horrocks, "Inhibitors of brain phospholipase A2 activity: their neuropharmacological effects and therapeutic importance for the treatment of neurologic disorders," Pharmacological Reviews, vol. 58, no. 3, pp. 591-620, 2006.

[129] G. Y. Sun, L. A. Horrocks, and A. A. Farooqui, "The roles of NADPH oxidase and phospholipases A in oxidative and inflammatory responses in neurodegenerative diseases," Journal of Neurochemistry, vol. 103, no. 1, pp. 1-16, 2007.

[130] A. A. Farooqui and L. A. Horrocks, "Phospholipase Agenerated lipid mediators in the brain: the good, the bad, and the ugly," Neuroscientist, vol. 12, no. 3, pp. 245-260, 2006.

[131] T. Yagami, "Cerebral arachidonate cascade in dementia: Alzheimer's disease and vascular dementia," Current Neuropharmacology, vol. 4, no. 1, pp. 87-100, 2006.

[132] S. Yedgar, Y. Cohen, and D. Shoseyov, "Control of phospholipase A activities for the treatment of inflammatory conditions," Biochimica et Biophysica Acta, vol. 1761, no. 11, pp. 1373-1382, 2006.

[133] E. A. Dennis, "Diversity of group types, regulation, and function of phospholipase A," The Journal of Biological Chemistry, vol. 269, no. 18, pp. 13057-13060, 1994.

[134] M. Murakami and I. Kudo, "Phospholipase A," Journal of Biochemistry, vol. 131, no. 3, pp. 285-292, 2002.

[135] G. Y. Sun, J. Xu, M. D. Jensen, and A. Simonyi, "Phospholipase A in the central nervous system: implications for neurodegenerative diseases," Journal of Lipid Research, vol. 45, no. 2, pp. 205-213, 2004.

[136] G. Y. Sun, J. Xu, M. D. Jensen et al., "Phospholipase A in astrocytes: responses to oxidative stress, inflammation, and G protein-coupled receptor agonists," Molecular Neurobiology, vol. 31, no. 1-3, pp. 27-41, 2005.

[137] V. Colangelo, J. Schurr, M. J. Ball, R. P. Pelaez, N. G. Bazan, and W. J. Lukiw, "Gene expression profiling of 12633 genes in Alzheimer hippocampal CA1: transcription and neurotrophic factor down-regulation and up-regulation of apoptotic and pro-inflammatory signaling," Journal of Neuroscience Research, vol. 70, no. 3, pp. 462-473, 2002.

[138] R. O. Sanchez-Mejia, J. W. Newman, S. Toh et al., "Phospholipase A reduction ameliorates cognitive deficits in a mouse model of Alzheimer's disease," Nature Neuroscience, vol. 11, no. 11, pp. 1311-1318, 2008. 
[139] C. Bate and A. Williams, "Squalestatin protects neurons and reduces the activation of cytoplasmic phospholipase A by A $\beta$," Neuropharmacology, vol. 53, no. 2, pp. 222-231, 2007.

[140] B. Kriem, I. Sponne, A. Fifre et al., "Cytosolic phospholipase A mediates neuronal apoptosis induced by soluble oligomers of the amyloid- $\beta$ peptide," FASEB Journal, vol. 19, no. 1, pp. 85-87, 2005.

[141] M. Chalimoniuk, A. Stolecka, M. Cakala et al., "Amyloid beta enhances cytosolic phospholipase A level and arachidonic acid release via nitric oxide in APP-transfected PC12 cells," Acta Biochimica Polonica, vol. 54, no. 3, pp. 611-623, 2007.

[142] P. B. Shelat, M. Chalimoniuk, J. H. Wang et al., "Amyloid beta peptide and NMDA induce ROS from NADPH oxidase and AA release from cytosolic phospholipase A in cortical neurons," Journal of Neurochemistry, vol. 106, no. 1, pp. 4555,2008

[143] S. Askarova and J. C. M. Lee, "Role of oligomeric AbetaRAGE interaction in NADPH oxidase complex assembly and ROS production in astrocytes and cerebral endothelial cells," unpublished data.

[144] W. F. Gattaz, O. V. Forlenza, L. L. Talib, N. R. Barbosa, and C. M. C. Bottino, "Platelet phospholipase A activity in Alzheimer's disease and mild cognitive impairment," Journal of Neural Transmission, vol. 111, no. 5, pp. 591-601, 2004.

[145] E. Krzystanek, M. Krzystanek, G. Opala, H. I. Trzeciak, J. Siuda, and A. Małecki, "Platelet phospholipase A activity in patients with Alzheimer's disease, vascular dementia and ischemic stroke," Journal of Neural Transmission, vol. 114, no. 8, pp. 1033-1039, 2007.

[146] W. F. Gattaz, A. Maras, N. J. Cairns, R. Levy, and H. Förstl, "Decreased phospholipase A activity in Alzheimer brains," Biological Psychiatry, vol. 37, no. 1, pp. 13-17, 1995.

[147] J. B. Hicks, Y. Lai, W. Sheng et al., "Amyloid- $\beta$ peptide induces temporal membrane biphasic changes in astrocytes through cytosolic phospholipase A," Biochimica et Biophysica Acta, vol. 1778, no. 11, pp. 2512-2519, 2008.

[148] D. Zhu, C. Hu, W. Sheng et al., "NAD $(\mathrm{P}) \mathrm{H}$ oxidase-mediated reactive oxygen species production alters astrocyte membrane molecular order via phospholipase A," Biochemical Journal, vol. 421, no. 2, pp. 201-210, 2009.

[149] M. S. Liu, S. Ghosh, and Y. Yang, "Change in membrane lipid fluidity induced by phospholipase an activation: a mechanism of endotoxic shock," Life Sciences, vol. 33, no. 20, pp. 1995-2002, 1983.

[150] E. L. Schaeffer, F. Bassi, and W. F. Gattaz, "Inhibition of phospholipase A activity reduces membrane fluidity in rat hippocampus," Journal of Neural Transmission, vol. 112, no. 5, pp. 641-647, 2005.

[151] G. P. Eckert, N. J. Cairns, A. Maras, W. F. Gattaz, and W. E. Müller, "Cholesterol modulates the membrane-disordering effects of beta-amyloid peptides in the hippocampus: specific changes in Alzheimer's disease," Dementia and Geriatric Cognitive Disorders, vol. 11, no. 4, pp. 181-186, 2000.

[152] B. M. Ross, A. Moszczynska, J. Erlich, and S. J. Kish, "Phospholipid-metabolizing enzymes in Alzheimer's disease: increased lysophospholipid acyltransferase activity and decreased phospholipase A activity," Journal of Neurochemistry, vol. 70, no. 2, pp. 786-793, 1998.

[153] O. V. Forlenza, E. L. Schaeffer, and W. F. Gattaz, "The role of phospholipase A in neuronal homeostasis and memory formation: implications for the pathogenesis of Alzheimer's disease," Journal of Neural Transmission, vol. 114, no. 2, pp. 231-238, 2007.
[154] R. Beck, S. Bertolino, S. E. Abbot, P. I. Aaronson, and S. V. Smirnov, "Modulation of arachidonic acid release and membrane fluidity by albumin in vascular smooth muscle and endothelial cells," Circulation Research, vol. 83, no. 9, pp. 923-931, 1998.

[155] A. Villacara, M. Spatz, R. F. Dodson, C. Corn, and J. Bembry, "Effect of arachidonic acid on cultured cerebromicrovascular endothelium: permeability, lipid peroxidation and membrane "fluidity"," Acta Neuropathologica, vol. 78, no. 3, pp. 310-316, 1989.

[156] X. Yang, W. Sheng, Y. He et al., "Secretory phospholipase A2 type III enhances $\alpha$-secretase-dependent amyloid precursor protein processing through alterations in membrane fluidity," Journal of Lipid Research, vol. 51, no. 5, pp. 957-966, 2010.

[157] D. Kögel, E. Copanaki, U. Hartig et al., "Modulation of membrane fluidity by omega 3 fatty acids: enhanced generation of sAPPalpha is required for the neuroprotective effects of DHA," in Proceedings of the 38th Annual Meeting of the Society for Neuroscience, 2008.

[158] I. V. J. Murray, M. E. Sindoni, and P. H. Axelsen, "Promotion of oxidative lipid membrane damage by amyloid $\beta$ proteins," Biochemistry, vol. 44, no. 37, pp. 12606-12613, 2005.

[159] J. K. Yao, T. M. Wengenack, G. L. Curran, and J. F. Poduslo, "Reduced membrane lipids in the cortex of alzheimer's disease transgenic mice," Neurochemical Research, vol. 34, no. 1, pp. 102-108, 2009.

[160] R. Williamson, A. Usardi, D. P. Hanger, and B. H. Anderton, "Membrane-bound $\beta$-amyloid oligomers are recruited into lipid rafts by a fyn-dependent mechanism," FASEB Journal, vol. 22, no. 5, pp. 1552-1559, 2008.

[161] M. Bokvist, F. Lindström, A. Watts, and G. Gröbner, "Two types of Alzheimer's $\beta$-amyloid (1-40) peptide membrane interactions: aggregation preventing transmembrane anchoring versus accelerated surface fibril formation," Journal of Molecular Biology, vol. 335, no. 4, pp. 1039-1049, 2004.

[162] P. T. Lansbury Jr., "Evolution of amyloid: what normal protein folding may tell us about fibrillogenesis and disease," Proceedings of the National Academy of Sciences of the United States of America, vol. 96, no. 7, pp. 3342-3344, 1999.

[163] S. Nag, J. Chen, J. Irudayaraj, and S. Maiti, "Measurement of the attachment and assembly of small amyloid- $\beta$ oligomers on live cell membranes at physiological concentrations using single-molecule tools," Biophysical Journal, vol. 99, no. 6, pp. 1969-1975, 2010.

[164] H. Jang, J. Zheng, R. Lal, and R. Nussinov, "New structures help the modeling of toxic amyloidß ion channels," Trends in Biochemical Sciences, vol. 33, no. 2, pp. 91-100, 2008.

[165] J. McLaurin and A. Chakrabartty, "Membrane disruption by Alzheimer $\beta$-amyloid peptides mediated through specific binding to either phospholipids or gangliosides. Implications for neurotoxicity," The Journal of Biological Chemistry, vol. 271, no. 43, pp. 26482-26489, 1996.

[166] M. J. O. Widenbrant, J. Rajadas, C. Sutardja, and G. G. Fuller, "Lipid-induced $\beta$-amyloid peptide assemblage fragmentation," Biophysical Journal, vol. 91, no. 11, pp. 40714080, 2006.

[167] G. P. Eckert, W. G. Wood, and W. E. Müller, "Effects of aging and beta-amyloid on the properties of brain synaptic and mitochondrial membranes," Journal of Neural Transmission, vol. 108, no. 8-9, pp. 1051-1064, 2001.

[168] C. M. Yip, A. A. Darabie, and J. McLaurin, "A $\beta 42-p e p t i d e$ assembly on lipid bilayers," Journal of Molecular Biology, vol. 318, no. 1, pp. 97-107, 2002. 
[169] S. A. Waschuk, E. A. Elton, A. A. Darabie, P. E. Fraser, and J. McLaurin, "Cellular Membrane Composition Defines A $\beta$ Lipid Interactions," The Journal of Biological Chemistry, vol. 276, no. 36, pp. 33561-33568, 2001.

[170] J. J. Kremer, M. M. Pallitto, D. J. Sklansky, and R. M. Murphy, "Correlation of $\beta$-amyloid aggregate size and hydrophobicity with decreased bilayer fluidity of model membranes," Biochemistry, vol. 39, no. 33, pp. 10309-10318, 2000.

[171] Y. Li, J. J. Wang, and J. X. Cai, "Aniracetam restores the effects of amyloid- $\beta$ protein or ageing on membrane fluidity and intracellular calcium concentration in mice synaptosomes," Journal of Neural Transmission, vol. 114, no. 11, pp. 14071411, 2007.

[172] D. Drago, M. Bettella, S. Bolognin et al., "Potential pathogenic role of $\beta$-amyloid1-42-aluminum complex in Alzheimer's disease," International Journal of Biochemistry and Cell Biology, vol. 40, no. 4, pp. 731-746, 2008.

[173] T. Parasassi, E. Gratton, W. M. Yu, P. Wilson, and M. Levi, "Two-photon fluorescence microscopy of laurdan generalized polarization domains in model and natural membranes," Biophysical Journal, vol. 72, no. 6, pp. 24132429, 1997.

[174] T. Parasassi, M. Di Stefano, G. Ravagnan, O. Sapora, and E. Gratton, "Membrane aging during cell growth ascertained by Laurdan generalized polarization," Experimental Cell Research, vol. 202, no. 2, pp. 432-439, 1992.

[175] S. Dante, T. Hauß, A. Brandt, and N. A. Dencher, "Membrane fusogenic activity of the Alzheimer's peptide $\mathrm{A} \beta(1-42)$ demonstrated by small-angle neutron scattering," Journal of Molecular Biology, vol. 376, no. 2, pp. 393-404, 2008.

[176] D. H. Kim and J. A. Frangos, "Effects of amyloid $\beta$-peptides on the lysis tension of lipid bilayer vesicles containing oxysterols," Biophysical Journal, vol. 95, no. 2, pp. 620-628, 2008.

[177] N. Arispe, H. B. Pollard, and E. Rojas, " $\mathrm{Zn}^{2+}$ interaction with Alzheimer amyloid $\beta$ protein calcium channels," Proceedings of the National Academy of Sciences of the United States of America, vol. 93, no. 4, pp. 1710-1715, 1996.

[178] G. Valincius, F. Heinrich, R. Budvytyte et al., "Soluble amyloid $\beta$-oligomers affect dielectric membrane properties by bilayer insertion and domain formation: implications for cell toxicity," Biophysical Journal, vol. 95, no. 10, pp. 48454861, 2008.

[179] J. M. Alarcón, J. A. Brito, T. Hermosilla, I. Atwater, D. Mears, and E. Rojas, "Ion channel formation by Alzheimer's disease amyloid $\beta$-peptide $(\mathrm{A} \beta 40)$ in unilamellar liposomes is determined by anionic phospholipids," Peptides, vol. 27, no. 1, pp. 95-104, 2006.

[180] N. Arispe, J. C. Diaz, and O. Simakova, “A $\beta$ ion channels. Prospects for treating Alzheimer's disease with $\mathrm{A} \beta$ channel blockers," Biochimica et Biophysica Acta, vol. 1768, no. 8, pp. 1952-1965, 2007.

[181] R. Lal, H. Lin, and A. P. Quist, "Amyloid beta ion channel: 3D structure and relevance to amyloid channel paradigm," Biochimica et Biophysica Acta, vol. 1768, no. 8, pp. 1966-1975, 2007.

[182] A. Quist, I. Doudevski, H. Lin et al., "Amyloid ion channels: a common structural link for protein-misfolding disease," Proceedings of the National Academy of Sciences of the United States of America, vol. 102, no. 30, pp. 10427-10432, 2005.

[183] T. Vaisid, N. S. Kosower, E. Elkind, and S. Barnoy, "Amyloid $\beta$ peptide toxicity in differentiated PC12 cells: calpaincalpastatin, caspase, and membrane damage," Journal of Neuroscience Research, vol. 86, no. 10, pp. 2314-2325, 2008.
[184] M. Kawahara, N. Arispe, Y. Kuroda, and E. Rojas, "Alzheimer's disease amyloid $\beta$-protein forms $\mathrm{Zn}^{2+}$-sensitive, cation- selective channels across excised membrane patches from hypothalamic neurons," Biophysical Journal, vol. 73, no. 1, pp. 67-75, 1997.

[185] F. J. Sepulveda, J. Parodi, R. W. Peoples, C. Opazo, and L. G. Aguayo, "Synaptotoxicity of Alzheimer beta amyloid can be explained by its membrane perforating property," PLOS ONE, vol. 5, no. 7, Article ID e11820, 2010.

[186] B. J. Blanchard, V. L. Thomas, and V. M. Ingram, "Mechanism of membrane depolarization caused by the Alzheimer A $\beta 1-42$ peptide," Biochemical and Biophysical Research Communications, vol. 293, no. 4, pp. 1197-1203, 2002.

[187] F. Chiti and C. M. Dobson, "Protein misfolding, functional amyloid, and human disease," Annual Review of Biochemistry, vol. 75, pp. 333-366, 2006.

[188] D. Liu, Y. Xu, Y. Feng et al., "Inhibitor discovery targeting the intermediate structure of $\beta$-amyloid peptide on the conformational transition pathway: implications in the aggregation mechanism of $\beta$-amyloid peptide," Biochemistry, vol. 45, no. 36, pp. 10963-10972, 2006.

[189] P. K. Mandal and J. W. Pettegrew, "Alzheimer's disease: soluble oligomeric $\mathrm{A} \beta(1-40)$ peptide in membrane mimic environment from solution NMR and circular dichroism studies," Neurochemical Research, vol. 29, no. 12, pp. 22672272, 2004.

[190] H. Song, S. Ritz, W. Knoll, and E. K. Sinner, "Conformation and topology of amyloid $\beta$-protein adsorbed on a tethered artificial membrane probed by surface plasmon fieldenhanced fluorescence spectroscopy," Journal of Structural Biology, vol. 168, no. 1, pp. 117-124, 2009.

[191] A. Wahlström, L. Hugonin, A. Perálvarez-Marín, J. Jarvet, and A. Gräslund, "Secondary structure conversions of Alzheimer's A $\beta(1-40)$ peptide induced by membranemimicking detergents," FEBS Journal, vol. 275, no. 20, pp. 5117-5128, 2008.

[192] T. Kowalewski and D. M. Holtzman, "In situ atomic force microscopy study of Alzheimer's $\beta$-amyloid peptide on different substrates: new insights into mechanism of $\beta$-sheet formation," Proceedings of the National Academy of Sciences of the United States of America, vol. 96, no. 7, pp. 3688-3693, 1999.

[193] T. Ban, K. Morigaki, H. Yagi et al., "Real-time and single fibril observation of the formation of amyloid $\beta$ spherulitic structures," The Journal of Biological Chemistry, vol. 281, no. 44, pp. 33677-33683, 2006.

[194] K. Yanagisawa, A. Odaka, N. Suzuki, and Y. Ihara, "GM1 ganglioside-bound amyloid $\beta$-protein $(\mathrm{A} \beta)$ : a possible form of preamyloid in Alzheimer's disease," Nature Medicine, vol. 1, no. 10, pp. 1062-1066, 1995.

[195] K. Yuyama, N. Yamamoto, and K. Yanagisawa, "Accelerated release of exosome-associated GM1 ganglioside (GM1) by endocytic pathway abnormality: another putative pathway for GM1-induced amyloid fibril formation," Journal of Neurochemistry, vol. 105, no. 1, pp. 217-224, 2008.

[196] K. Matsuzaki and C. Horikiri, "Interactions of amyloid $\beta$-peptide (1-40) with ganglioside-containing membranes," Biochemistry, vol. 38, no. 13, pp. 4137-4142, 1999. 


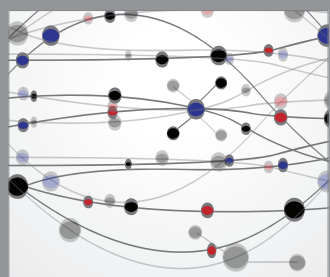

The Scientific World Journal
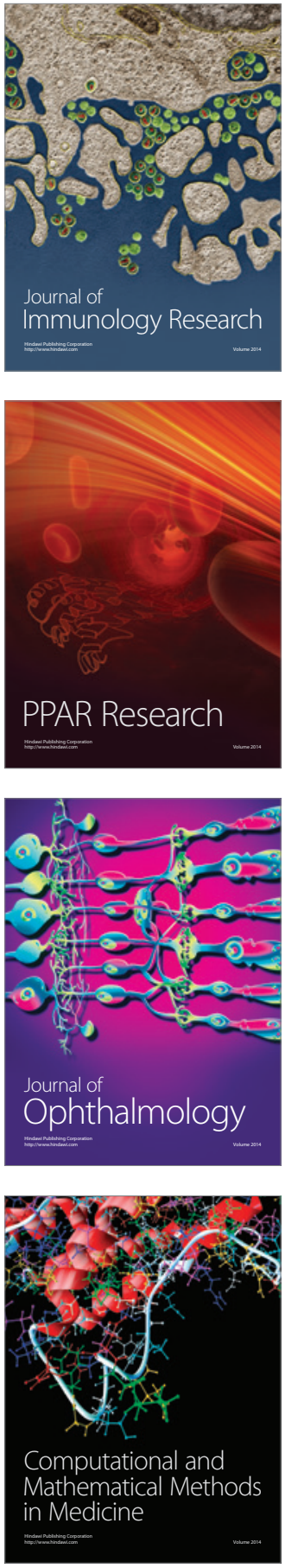

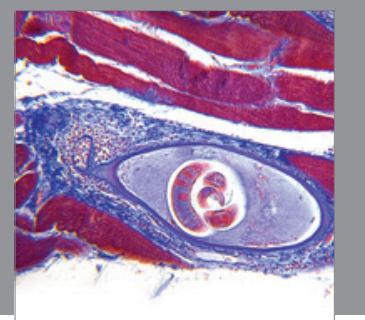

Gastroenterology

Research and Practice
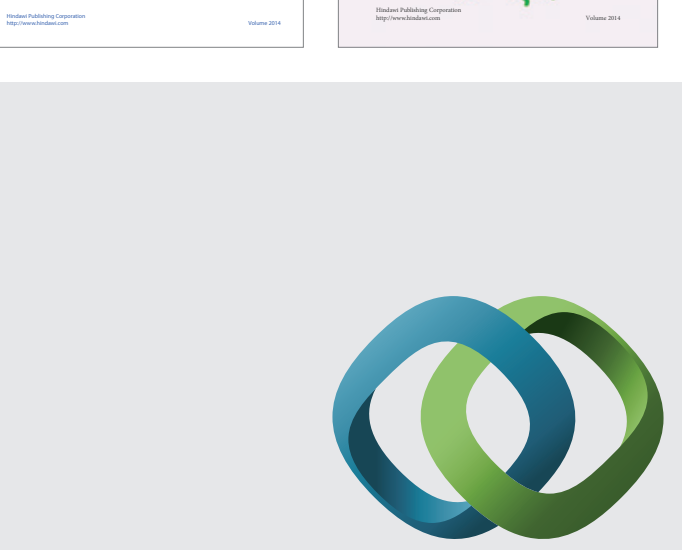

\section{Hindawi}

Submit your manuscripts at

http://www.hindawi.com
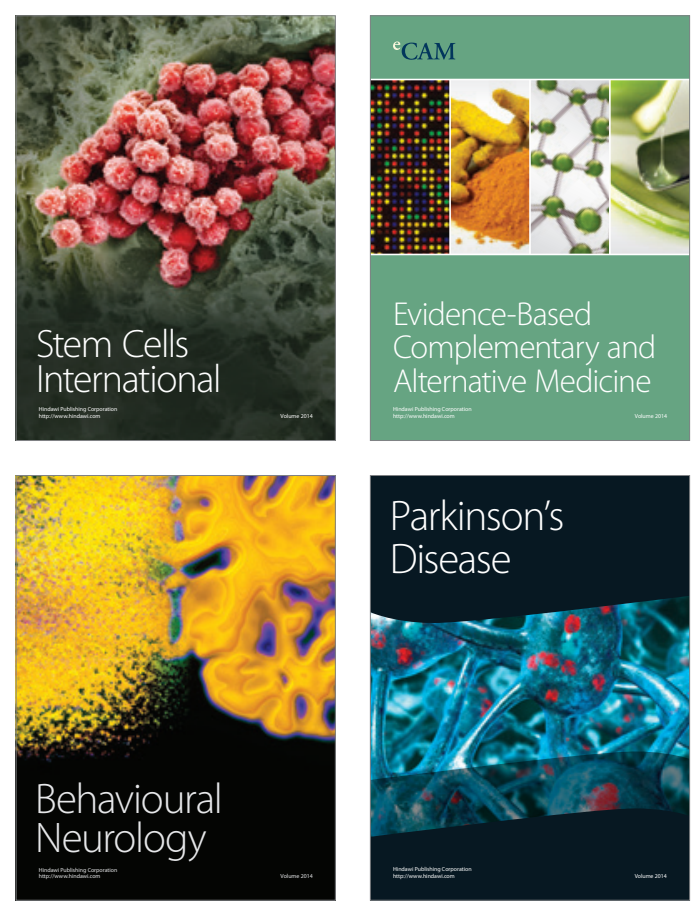

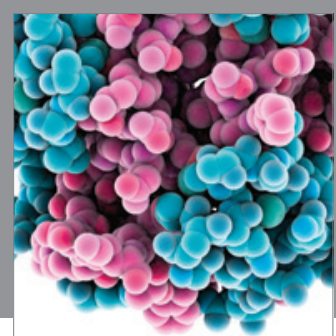

Journal of
Diabetes Research

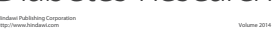

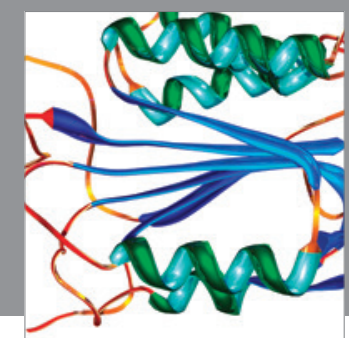

Disease Markers
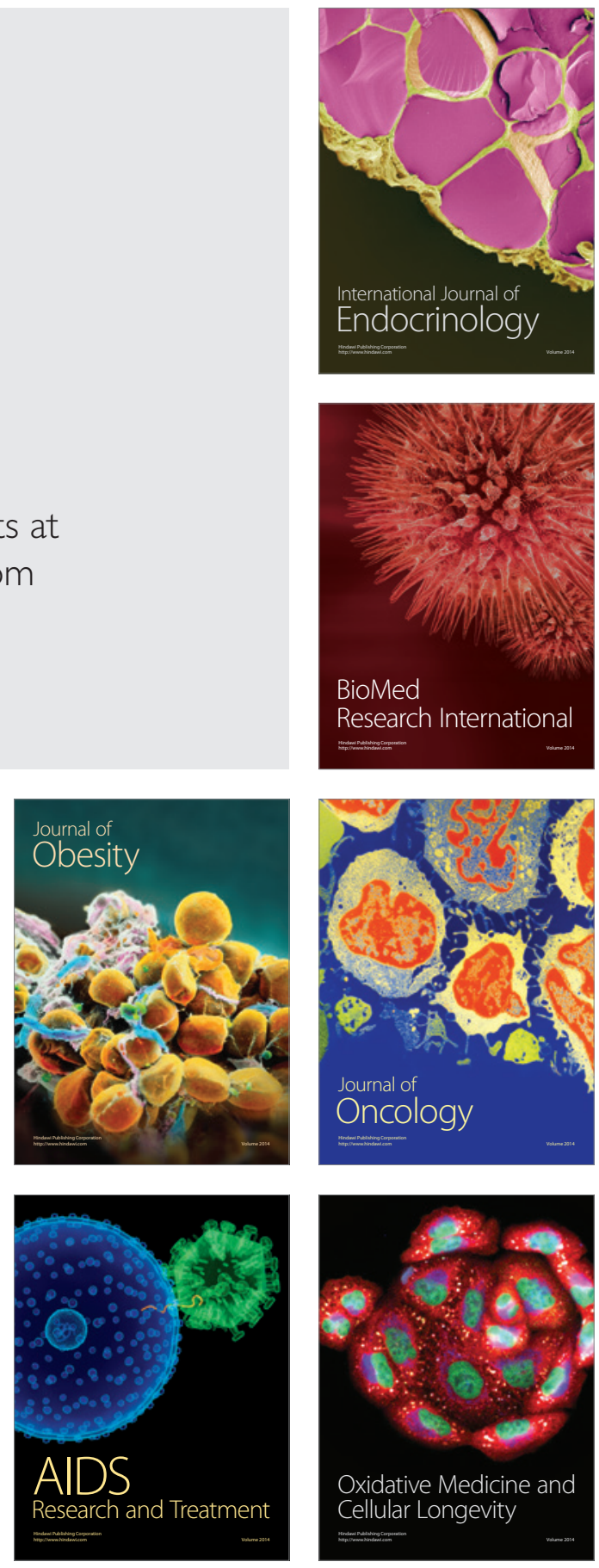